\title{
Stability of Collagen Scaffold Implants for Animals with Iatrogenic Articular Cartilage Defects
}

\author{
Josef Jančáŕ ${ }^{1}$, Lucy Vojtová1, Alois Nečas ${ }^{2}$, Robert Srnec ${ }^{2}$, Lucie Urbanová2, \\ Michal Crha \\ ${ }^{1}$ Institute of Materials Chemistry, Brno University of Technology, Czech Republic \\ ${ }^{2}$ Department of Surgery and Orthopaedics, Small Animal Clinic, Faculty of Veterinary Medicine, \\ University of Veterinary and Pharmaceutical Sciences Brno, Czech Republic
}

Received May 14, 2009

Accepted September 8, 2009

\begin{abstract}
Synthesis and characterization of biodegradable hydrogels based on collagen modified by addition of synthetic biodegradable copolymer intended for preparation of porous scaffolds for mesenchymal stem cells used for possible implantation to animals with articular surface defects was investigated.

The synthetic biodegradable tri-block copolymer used was the block copolymer of polyethylene glycol (PEG), polylactic acid (PLA), polyglycolic acid (PGA) (PEG-PLGA) endcapped with itaconic acid (ITA). The water-soluble carbodiimide and N-hydroxysuccimide system (EDC-NHS) was chosen as the cross-linking agent used to control the rate of hydrogel resorption. Dependence of the physical properties of the prepared hydrogels on the concentration of the EDC-NHS cross-linker, reaction time and concentration of PEG-PLGA-ITA copolymer was examined. Swelling behaviour, thermal stability, surface morphology and degradation rate were also characterized.

Based on the obtained results, it can be concluded that increase in concentration of the cross-linking agent, as well as prolonged cross-linking time and increased amount of synthetic copolymer lead to enhanced thermal stability of the gels together with a reduced swelling ratio and degradation rate in saline. The resorption rate of these gels used in preparation of cartilage scaffolds can be controlled over a wide time interval by varying the collagen/(PEG-PLGA-ITA) blend composition or the conditions of the cross-linking reaction.
\end{abstract}

Collagen, PEG, PLGA, ITA, cross-linking, EDC, scaffold

Collagen extracted from bovine skin is one of the most often used biopolymers in various medical applications due to its inherent biocompatibility, ability to support cell growth and differentiation and negligible immuno-reactivity. On the other hand, collagen exhibits poor mechanical properties and low stability in various physiologically important solvents. To overcome its shortcomings, collagen can be blended with other polymers, filled with solid inclusions or cross-linked (Langer and Vacanti 1993).

Cross-linking of collagen using the reactive hydroxy-, amino- and carboxy- groups on the collagen molecule has been described previously (Herink and Van Nostrum 2002; Marquie 2001; Lynn et al. 1998; Zeeman 1998; Damink et al. 1996; Purna and Babu 2000). So far, various aldehydes have been used as the cross-linking agents. The main shortcoming of aldehydes is their toxicity and poor reactivity requiring lengthy removal of the residues prior to use in experimental animals or patients (Henink and Van Nostrum 2002; Marquie 2001). Recently, non-toxic cross-linking agent has been described based on water-soluble carbodiimide and N-hydroxysuccimide (EDC-NHS) (Zeeman 1998; Olde Damink et al. 1996; Purna and Babu 2000).

Polylactide acid (PLA), polyglycolide acid (PGA) or their copolymer (PLGA) are the best known synthetic biodegradable polymers considered in medicine (Hennink and Van Nostrum 2002). Polyethylene glycol (PEG) is a hydrophilic and non-degradable biomaterial. Block copolymerization of PEG and polyesters (PEG-PLGA) is a way to

Address for correspondence:

Prof. RNDr. Josef Jančár, CSc.

Institute of Materials Chemistry

Faculty of Chemistry, Brno University of Technology

Purkyñova 118, 61200 Brno, Czech Republic
Phone:
Fax:
E-mail: jancar@fch.vutbr.cz
http://www.vfu.cz/acta-vet/actavet.htm 
combine advantages of biodegradable polyesters and polyethylene glycol (Metters et al. 2000). Reactive double bonds and carboxyl groups can be added to PEG-PLGA copolymer through addition of itaconic anhydride (ITA). The carboxyl groups result in increasing hydrophility, reactivity, biocompatibility, bioinduction and material adhesion. Double bonds can be used for radical cross-linking of the hydrogels using various techniques employing electromagnetic radiation. Further, the carboxyl groups can react with chemical compounds such as drugs and can be used in controlled drug delivery systems (Vojtová et al. 2006). Most of the synthetic polymer biomaterials exhibit good mechanical properties but their biological properties are poor. On the other hand, natural biopolymers exhibit excellent biological properties, however, they lack the biomechanical properties required by the specific medical applications. In order to obviate these shortcomings, synthetic and natural biopolymers, e.g. PEG-PLGA polyesters and collagen, can be combined in blends, inter-penetrating networks or copolymers.

In this paper, preparation and cross-linking of transparent biodegradable hydrogels based on collagen modified by addition of PEG-PLGA-ITA copolymer was investigated. Dependence of the physical properties of the prepared hydrogels on concentration of EDCNHS, cross-linking reaction time and concentration of the copolymer was investigated. Swelling behaviour, thermal properties surface morphology and degradation rate of the prepared hydrogels were characterized. Use of these gels in preparation of lyophilized porous cartilage scaffolds with controlled pore size has also been investigated.

\section{Materials and Methods}

Polyethylene glycol (PEG) (Sigma-Aldrich, USA) was re-crystallised from dimethylmethane solution. Lactide anhydride (LA) and glycolide anhydride (GA) (Polysciences Inc., USA) and $95 \mathrm{wt} \%$ solution of stanous-2ethylhexanoate were used as received. Bovine collagen I was supplied in the native form as the 8 wt $\%$ aqueous solution (VUP, a.s., Czech Republic), $\mathrm{M}_{\mathrm{w}}=300$ 000. The 1-ethyl-3-(3-dimethylaminopropyl)-carbodiimide hydrochloride (EDC) and N-hydroxysuccinimide (NHS) (Sigma-Aldrich, USA) were used as received. The copolymers based on PEG-PLGA $\left(M_{n}=4843\right)$ and PEG-PLGA-ITA $\left(M_{n}=4944\right)$ (Fig. 1) were prepared by ringopening copolymerization (Hubbell 1995 ). The $1 \mathrm{wt} \%$ solution of collagen and $2.5 \mathrm{wt} \%$ solution of prepared copolymer of PEG-PLGA or PEG-PLGA-ITA were mixed in various mass ratio in a mixer (IKA Turrax Basic T18) and air-dried in Petri dishes.

Molar and weight ratios between GA and LA, molar ratio between PEG and PLGA and total molecular weight were determined using ${ }^{1} \mathrm{HNMR}$ analysis $\left({ }^{1} \mathrm{HNMR}\right.$, Bruker $\left.500 \mathrm{MHz}, \mathrm{USA}\right)$. The measurements were performed in $\mathrm{CDCl}_{3}$ solution using $500 \mathrm{MHz}$ and 128 scans. Molecular weight and polydispersity of both PEG-PLGA and PEG-PLGA-ITA copolymers were determined using GPC analysis (Agilent Technologies 1100 Series, USA). Tetrahydrofuran was used as the mobile phase $\left(1 \mathrm{ml} \cdot \mathrm{min}^{-1}\right)$ and polystyrene weight fractions as the standards. Thermal behaviours of pure and modified collagen films were measured employing differential scanning calorimeter (DSC TA Instruments 2920, USA) over the temperature range from 35 to $140{ }^{\circ} \mathrm{C}$ at the heating rate of $5{ }^{\circ} \mathrm{C} / \mathrm{min}$. Prior to each measurement, the dry film samples were swelled in saline $(0.9 \mathrm{wt} \% \mathrm{NaCl}$ solution $)$ for one hour.

The modified collagen films were cross-linked using the EDC-NHS, where the molar ratio of EDC and NHS in the cross-linking solution was 2:1. Two different types of cross-linking conditions were chosen. First, the EDC concentration was varied $(5,25$ and $50 \mathrm{mmol} / \mathrm{l})$ and the cross-linking time was kept constant at $4 \mathrm{~h}$. Secondly, the cross-linking time was varied $(0.25,1$ and $4 \mathrm{~h})$ and the EDC-NHS concentration was kept constant equal to $50 \mathrm{mmol} / 1$.

After completing the cross-linking reaction, samples were washed for $2 \mathrm{~h}$ with $0.1 \mathrm{M} \mathrm{Na}_{2} \mathrm{HPO}_{4}$ solution to remove unreacted EDC, and then washed for $2 \mathrm{~h}$ in distilled water. Finally, the samples were air-dried. After these steps, the transparent, cross-linked and modified collagen films were obtained. Prior to measurements, thickness and weight of the sample films has been determined.

Aqueous solutions containing $20 \mathrm{wt} \%$ of the PLA-PGA-PEG or PLA-PGA-PEG-ITA were mixed with $5 \mathrm{wt} \%$ collagen solution. The mixtures were homogenized for $5 \mathrm{~min}$ and then centrifuged to remove air bubbles. The homogeneous solution was frozen at $-35{ }^{\circ} \mathrm{C}$ for $24 \mathrm{~h}$. Then, samples were lyophilized at $-55^{\circ} \mathrm{C}$ and $15 \mathrm{~Pa}$ for 24 h. Nucleating agents were used to control the size of water crystals in order to prepare porous scaffolds with the desired pore size.

The swelling ratio between the sample mass after the swelling and the sample mass before the swelling was measured. The swelling ratio was calculated after the swelling pure and modified collagenous films in saline for one hour. Film surface morphology was studied using the confocal scanning laser microscope (Olympus - Lext OLS 3000 Japan). Films with varying composition which were cross-linked using $25 \mathrm{mmol} \cdot \mathrm{l}^{-1}$ EDC solution 
were observed. Before the observation, samples were washed out with acetone to remove the present synthtetic copolymer resulting in highlighting the surface. The degradation rate was examined in saline using $\mathrm{CO}_{2}$ incubator (Sanyo MCO-18AlC, Japan) at $37^{\circ} \mathrm{C}$.

\section{Results and Discussion}

The average molecular weight, $\mathrm{M}_{n}$, polydispersity, $\mathrm{M}_{\mathrm{w}} / \mathrm{M}_{\mathrm{n}}$, molar and weight ratios between the co-monomers in the copolymer obtained from the ${ }^{1}$ HNMR and GPC analyses are summarized in Table 1. Based on the obtained results, we can conclude that the molecular structure of the prepared copolymers was in good agreement with the theoretically predicted molecular structure.

Table 1. GPC and ${ }^{1} \mathrm{HNMR}$ analysis results

\begin{tabular}{|l|c|c|c|c|c|}
\hline & Theory & \multicolumn{2}{|c|}{ GPC } & \multicolumn{2}{c|}{${ }^{1}$ HNMR } \\
\hline Property & & PEG-PLGA & PEG-PLGA-ITA & PEG-PLGA & PEG-PLGA-ITA \\
\hline Molecular weight (Mn) & 5250 & 7108 & 6773 & 4843 & 4944 \\
\hline Polydispersity (Mw/Mn) & 1 & 1.18 & 1.22 & - & - \\
\hline Molar ratio PLA/PGA & 3 & - & - & 2.87 & 2.83 \\
\hline Weight ratio PLGA/PEG & 2.5 & - & - & 2.23 & 2.3 \\
\hline
\end{tabular}

\section{Scaffold preparation}

The crystallization of water is a process controlling the pore size, pore size distribution and pore connectivity in the collagen/PLA-PGA-PEG scaffolds prepared using lyophilization. In order to control the pore size, mineral additives were added to alter crystal nucleation rate. In addition, the observed differences in pore size and overall porosity of scaffolds prepared from different collagen mixtures were related to the change in hydrophylicity occurring with varying molecular structure and content of the modifying copolymer.

The collagen-PEG-PLGA and collagen-PEG-PLGA-ITA scaffolds exhibited high porosity in comparison with pure collagen scaffolds. The porosity decreased after crosslinking in the following order: collagen-PEG-PLGA > collagen-PEG-PLGA-ITA > pure collagen with the corresponding porosity of $81 \%>80 \%>47 \%$, respectively. Morphology of cross-linked collagen sponges modified with different additive in concentration of $20 \%$ is shown in Fig. 9 (Plate XI).

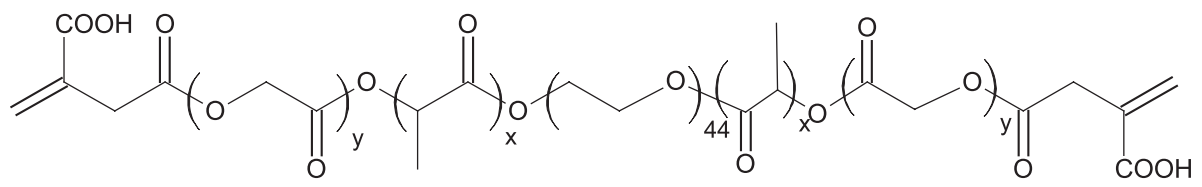

Fig. 1. Copolymer ITA - p(LA-co-GA) - b - PEG - b - p(LA-co- GA) - ITA

Thermal behaviour

Thermal behaviour of pure cross-linked collagen films and cross-linked collagen films modified with PEG-PLGA and PEG-PLGA-ITA copolymers are similar. The total amount of heat, determined as the area under the $c_{p}$ vs. T plot obtained from DSC measurement decreased with increasing cross-linking time (Fig. 2) and with concentration of the EDCNHS cross-linker (Fig. 3). Since most of the heat was consumed to evaporate water, this phenomenon can be attributed to the reduction of the swelling capability with enhanced cross-link density. 


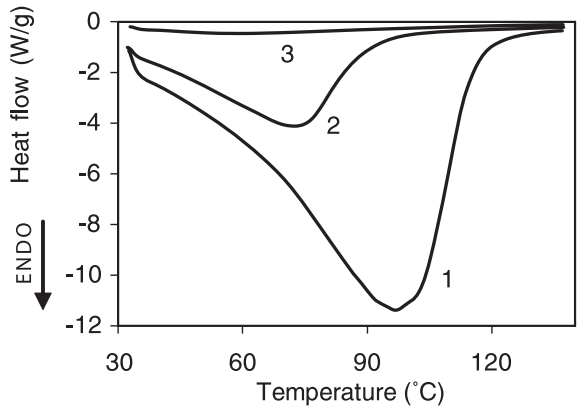

Fig. 2. Influence of cross-linking time on thermal behaviour of collagen films with 20\% PEG-PLGA; $2.25 \mathrm{~h}$ (line 1), $1 \mathrm{~h}$ (line 2), $4 \mathrm{~h}$ (line 3 )

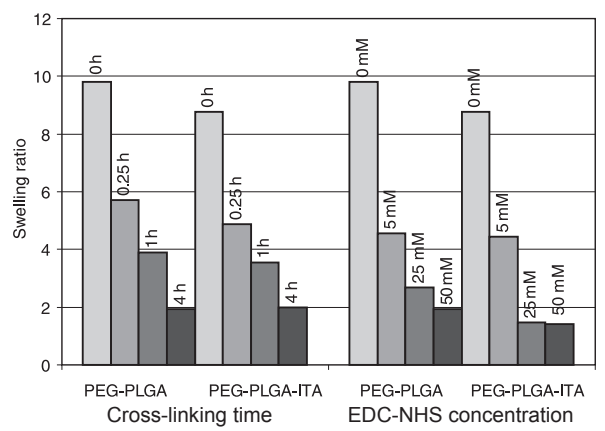

Fig. 4. Comparison of all cross-linking conditions used on collagenous film with $20 \%$ copolymer

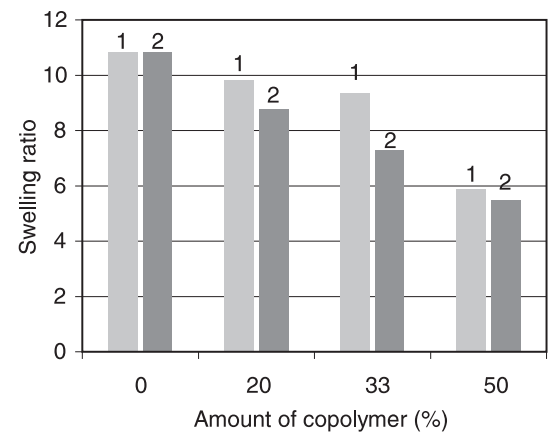

Fig. 6. Comparison of PEG-PLGA (columns 1) and PEG-PLGA-ITA (columns 2) copolymers on swelling behaviour of modified films

\section{Swelling behaviour}

Collagen modified with both types of co-polymers, i.e., PEG-PLGA and PEG-PLGAITA, exhibited similar swelling behaviour. The swelling ratio decreased with increasing cross-linking time and EDC-NHS concentration as expected (Fig. 4). This phenomenon
Fig. 3. Influence of cross-linking agent concentration on the thermal behaviour of pure collagen film; $5 \mathrm{mml} \cdot 1^{-1}$ EDC (line 1), $25 \mathrm{mmol} \cdot 1^{-1} \mathrm{EDC}$ (line 2), $50 \mathrm{mmol} \cdot 1^{-1}$ EDC (line 3)

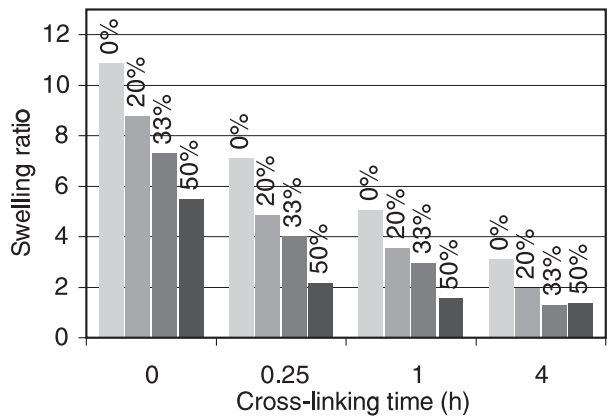

Fig. 5. Influence of copolymer amoount during various cross-linking times

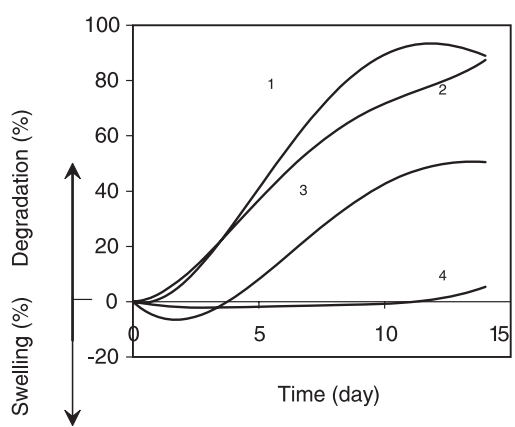

Fig. 8 Influence of degradation rate on pure collagen (line 1), collagen with $20 \%$ of PEG-PLGA (line 2), collagen with $33 \%$ of PEG-PLGA (line 3 ) and collagen with $50 \%$ of PEG-PLGA (line 4 ) cross-linked with 50 $\mathrm{mmol} \cdot \mathrm{l}^{-1}$ EDC-NHS for $15 \mathrm{~min}$ 
was caused by the enhanced cross-link density. In addition, the water absorption was inversely proportional to the concentration of the block copolymer in the mixture (Fig. 5). This feature was caused by the lower water absorption of the copolymer phase. In addition, collagen modified with PEG-PLGA-ITA swelled less than that containing copolymer based on PEG-PLGA at the same weight fraction (Fig. 6). It can be assumed that the carboxyl end-groups of ITA can react with free amino groups on the collagen molecule to form a peptide bond. This peptide bond contributes to further increase in the cross-link density in modified films resulting in a decrease of the swelling ratio.

\section{Degradation rate}

The surface morphology of various collagen films was correlated with the amount of copolymer added. The pure cross-linked collagen films exhibited a smooth surface while addition of the copolymer resulted in coarser surface morphology, suggesting poor miscibility between collagen and the modifying copolymers. After dissolving the copolymer phase using acetone, coarse collagen fibrils were observed on the surface of the film with $50 \mathrm{wt} \%$ of the copolymer (Plate XI, Fig. 7) which was attributed to the self-assembly process of collagen triple-helices into microfibrils approximately $15 \mathrm{~mm}$ in diameter. This process leads to formation of microfibrils in living tissues, however, its kinetics and thermodynamic features are not well described. It seems that the reactive carboxyls on the tri-block copolymer can occupy the N-termini of collagen and, thus, effectively reduce its ability to cross-link. Consequently, the collagen undergoes "crystallisation"-like process resulting in microfibril formation as predicted theoretically more than 50 years ago.

The increasing amount of both PEG-PLGA and PEG-PLGA-ITA copolymers lead to a decreasing degradation rate. In other words, the addition of the PEG-PLA-PGA copolymer can enhance the stability of the scaffold. We assumed that higher hydrophobicity of both copolymers is responsible for increasing resistivity to water uptake and hydrolysis (Fig. 8).

It can be concluded that an increase in concentration of the cross-linking agent, as well as prolonged cross-linking time and increased amount of synthetic copolymer lead to enhanced thermal stability of the gels together with reduced swelling ratio and degradation rate in a saline. The resorption rate of these gels used in preparation of cartilage scaffolds can be controlled over a wide time interval by varying the collagen/(PEG-PLGA-ITA) blend composition or the conditions of the cross-linking reaction. Composition of the blend has a strong effect on the supermolecular structure of the collagenous phase. Above certain concentration of PEG-PLGA-ITA copolymer, strong trend towards self-assembly of collagen molecules into microfibrils was observed. These findings can be helpful in preparation of porous scaffolds for mesenchymal stem cells (MSCs) used in animals and humans. In vivo properties after surgical implantation of the scaffolds seeded with MSCs to experimental animal model are currently being investigated in miniature pigs with articular cartilage defects.

\section{Stabilita kolageních skafoldů určených pro implantaci do iatrogenně vytvořených defektů kloubních chrupavek u zvířat}

Práce se zabývá syntézou a popisem biodegradabilního hydrogelu vyrobeného modifikací kolagenu přidáním syntetického biodegradabilního kopolymeru. Tento hydrogel byl určen pro přípravu porézního skafoldu, který po osazení mesenchymálními kmenovými buňky může být využit pro transplantace do defektů kloubních chrupavek u zvírat.

Tř́rozměrný syntetický biodegradabilní kopolymer byl tvořen kopolymerem polyethylen glykolu (PEG), polymeru mléčné kyseliny (PLA), polyglykolové kyseliny (PGA) (PEG-PLGA) ukončených kyselinou itakonovou (ITA). Pro vyhodnocení míry resorpce hydrogelu byl použit ve vodě rozpustný carbodiimide and N-hydroxysuccimide systém (EDC-NHS). Byla zhodnocena závislost fyzikálních vlastností připraveného hydrogelu na koncentraci EDC-NHS, reakčním času a koncentraci PEG-PLGA-ITA kopolymeru, rovněž 
bylo sledováno bobtnací chování, teplotní stabilita, morfologie povrchu a rychlost degradace hydrogelu.

$\mathrm{Na}$ základě námi získaných výsledků můžeme tvrdit, že zvýšená koncentrace EDCNHS, tak jako množství syntetického kopolymeru, vede k zlepšení teplotní stability gelů společně se snížením stupně otoku a rychlosti jejich degradace ve fyziologickém roztoku. Resorpční rychlost u těchto gelů použitých $\mathrm{k}$ přípravě skafoldů do chrupavek může být řízena během širokého časového intervalu složením směsi kolagen/(PEG-PLGA-ITA), nebo změnou podmínek sít’ovací reakce.

\section{Acknowledgements}

Financial support of this research under NPV II project 2B06130 from the Ministry of Education, Youth and Sports is greatly appreciated.

\section{References}

Olde Damink LH, Dijkstra PJ, Van Luyn MJ, Van Wachem PB, Nieuwenhuis P, Feijen J 1996: Cross-linking of dermal sheep collagen using a water-soluble carbodiimide. Biomaterials 17: 765-73

Hennink WE, Van Nostrum CF 2002: Novel crosslinking methods to design hydrogels. Adv Drug Deliv Rev 54: 13-36

Hubbell JA 1995: Biomaterials in tissue engineering. Biotechnology 13: 565-576

Langer R, Vacanti JP1993: Tissue engineering. Science 260: 920-926

Huang LL, Lee PC, Chen LW, Hsieh KH 1998: Comparison of epoxides on grafting collagen to polyurethane and their effects on cellular growth. J Biomed Mater Res 39: 630-636

Mano JF, Sousa RA, Boesel LF, Neves NM, Reis RL 2004: Bioinert, biodegradable and injectable polymeric matrix composites for hard tissue replacement: State of the art and recent developments. Compos Sci Technol 64: $789-817$

Marquié C 2001: Chemical reactions in cottonseed protein cross-linking by formaldehyde, glutaraldehyde, and glyoxal for the formation of protein films with enhanced mechanical properties. J Agric Food Chem 49: 46764681

Metters AT, Anseth KS, Bowman CN 2000: Fundamental studies of a novel, biodegradable PEG-b-PLA hydrogel. Polymer 41: 3993-4004

Purna SK, Babu M 2000: Collagen based dressings - A review. Burns 26: 54-62

Vojtová L, Nová L, Vávrová M, Chytil M, Pekař M, Jančář J 2006: Synthesis and Sol-gel Transition of Injectable Biodegradable Thermosensitive PLGA-PEG-PLGA Copolymers Modified by Itaconic Acid. Proceedings of Macro 2006, National Chemical Laboratory (Ed.), Pune, India, PHC-P1 p.

Zeeman R 1998: Cross-linking of collagen-based materials. PhD. Thesis, Febodruk BV, Enschede, The Netherlands, p. 199 
Plate XI

Jančář J. et al.: Stability of Collagen ... pp. 643-648

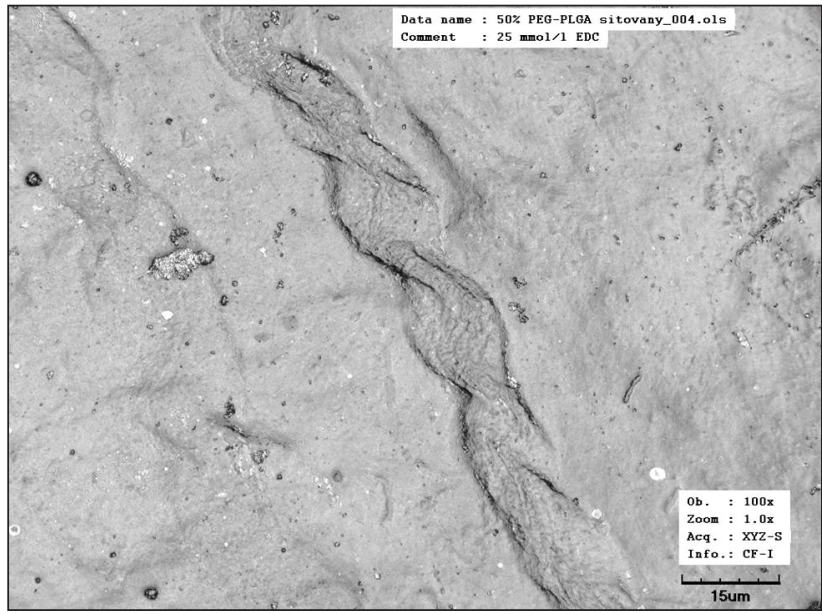

Fig. 7. Collagen fibril on the surface of collagen film containing 50 wt. \% of PEG-PLGA crosslinked with $25 \mathrm{mmol} \cdot \mathrm{l}^{-1}$ EDC. Film was etched in acetone for $24 \mathrm{~h}$ at $25^{\circ} \mathrm{C}$. 

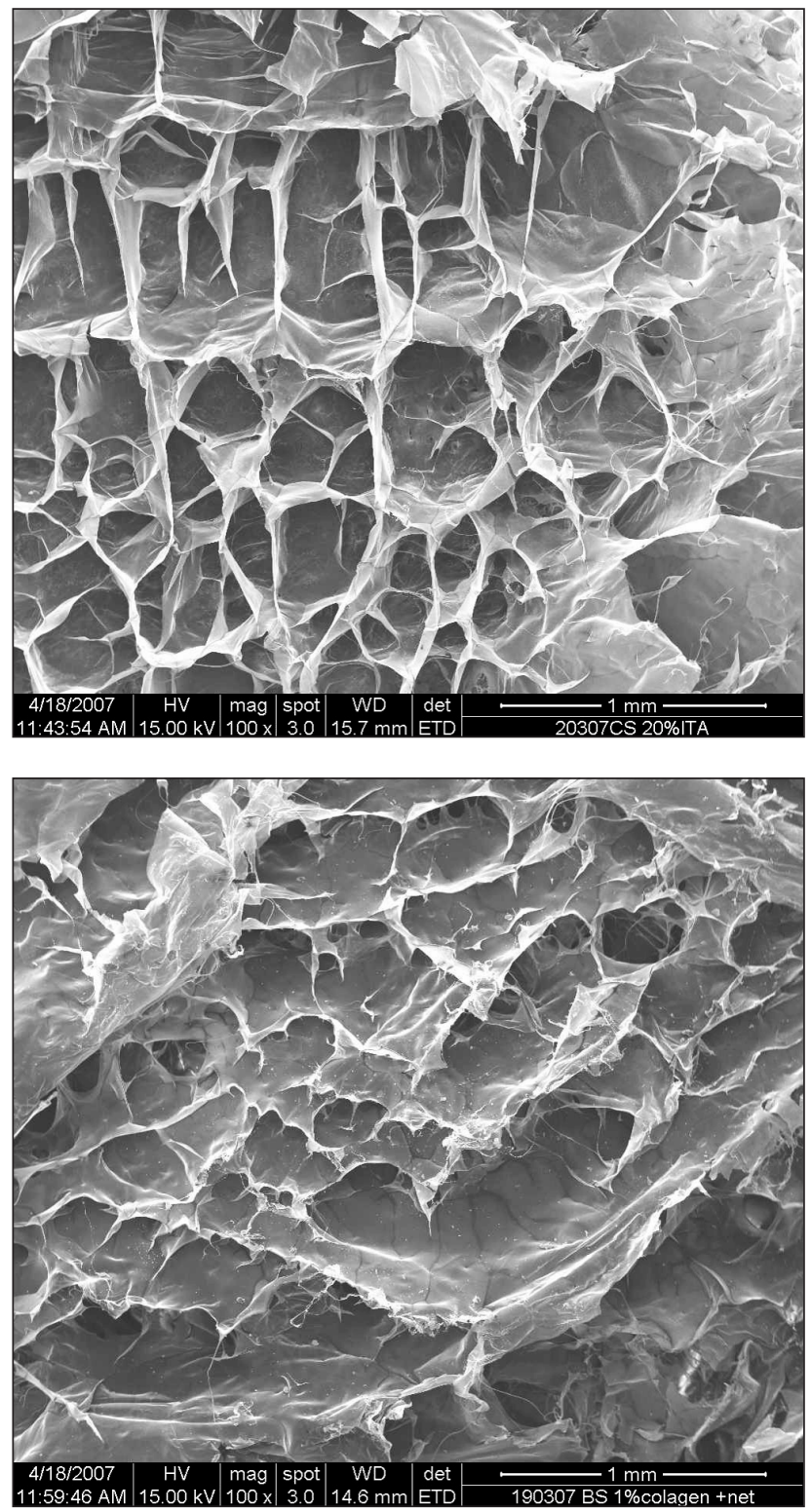

Fig. 9. Morphology of scaffolds based on cross-linked collagen with 20 wt. \% of a) PEG-PLGA and b) PEG-PLGA-ITA observed using SEM. 